\title{
Risk of MS relapse after yellow fever vaccination
}

A self-controlled case series

Angela Huttner, MD, Gilles Eperon, MD, Agustina M. Lascano, MD, PhD, Serge Roth, MD, Jean-Marc Schwob, MD, Claire-Anne Siegrist, MD, and Patrice H. Lalive, MD

Neurol Neuroimmunol Neuroinflamm 2020;7:e726. doi:10.1212/NXI.0000000000000726

\section{Abstract}

\section{Objective}

To determine whether live-attenuated yellow fever vaccine (YFV) was associated with MS relapse, we evaluated the clinical courses of 23 patients in the year before and the year after immunization at the university hospital of Geneva, Switzerland.

\section{Methods}

This self-controlled retrospective cohort included adult patients with MS receiving YFV between 2014 and 2018 and defined the year before vaccination, the 3 months thereafter, and the 9 months following as the pre-exposure (PEP), exposure-risk (ERP), and postrisk (PRP) periods, respectively. The primary outcome was the relative incidence of relapse in the ERP vs the PEP. Secondary end points included the presence of new T2-weighted (T2) or T1weighted gadolinium-positive (T1Gd+) MRI lesions.

\section{Results}

Of 23 patients with MS receiving YFV (20 relapsing MS and 3 primary progressive MS), 17 (74\%) were women; mean age was 34 years (SD \pm 10$)$; and 10 of $23(40 \%)$ were treated with disease-modifying therapies (DMTs). Although 9 patients experienced 12 relapses in the PEP, only one experienced a relapse in the ERP; 3 other patients experienced one relapse each in the PRP. None of the 8 patients receiving natalizumab at the time of vaccination experienced relapse thereafter. In the PEP, ERP, and PRP, 18, 2, and 9 patients had new brain and/or spinal cord lesions on T2 or T1Gd + MRI, respectively.

\section{Conclusions}

In this cohort, YF vaccination was associated with neither an increase in MS relapse nor emergence of brain and/or spinal lesions. Further studies are warranted to confirm these findings.

\section{Classification of evidence}

This study provides Class IV evidence that for persons with MS, YFV may not increase relapse risk.

\author{
Correspondence \\ Dr. Lalive \\ patrice.lalive@hcuge.ch
}

\section{MORE ONLINE}

$\rightarrow$ Class of Evidence

Criteria for rating therapeutic and diagnostic studies

NPub.org/coe 


\section{Glossary}

ARR = annualized relapse rate; $\mathbf{D M T}=$ disease-modifying therapy; ERP = exposure-risk period; $\mathbf{Y F}=$ yellow fever; $\mathbf{Y F V}=$ yellow fever vaccine; $\mathbf{P E P}=$ pre-exposure risk period; $\mathbf{P R P}=$ postrisk period.

Yellow fever (YF) is a severe disease without specific therapy that is expanding its territory. ${ }^{1}$ Yellow fever vaccine (YFV) is highly effective, inducing neutralizing antibodies in $99 \%$ of recipients. $^{2}$ This live-attenuated vaccine can cause transient inflammatory reactions and, rarely, severe adverse events. ${ }^{3}$

Because viral infections may trigger ${ }^{4}$ or worsen autoimmune diseases, ${ }^{5}$ it is plausible that YFV could do the same. No prospective evaluation of the effects of YFV on the course of MS has been conducted. In 2011, a significantly higher collective incidence of MS relapse and MRI activity was reported in 5 of 7 patients after YFV. ${ }^{6}$

After individualized risk-benefit assessments, our center offers vaccination to patients with MS at risk of YF exposure. We report the pre- and post-YFV clinical courses of 23 patients with MS.

\section{Methods}

\section{Study design, population, and entry criteria}

This single-center retrospective cohort study uses the selfcontrolled case series method, ${ }^{7}$ defining the pre-exposure risk period (PEP) as the 12 months preceding vaccination, the exposure-risk period (ERP) as the 3 months after vaccination, and the postrisk period (PRP) as the 4 to 12 months thereafter (figure e-1, links.lww.com/NXI/A249). The primary outcome was the relative incidence of MS relapse in the ERP vs the PEP (Class IV evidence level). Secondary outcomes included the presence of new T2-weighted (T2) or T1-weighted gadolinium-positive (T1Gd+) MRI lesions. Enlarging T2 lesions were not included, given high inter-rater variability, with poor agreement on lesion count largely because of technical aspects $^{8}$; the first MRIs in this retrospective study were performed in 2013 before awareness of this issue was widespread.

A relapse was defined as a monophasic clinical episode with patient-reported symptoms and objective findings typical of MS developing acutely or subacutely with a duration of at least 24 hours, with or without recovery, in the absence of fever or infection. ${ }^{9}$

All adult patients diagnosed with MS according to the 2010 or 2015 McDonald criteria ${ }^{9}$ and vaccinated with YFV (Stamaril, Sanofi-Aventis) from January 2014, when an electronic health record for structured MS clinical data was established, through June 2018 were eligible.

In our center, patients with MS receive YFV at the clinician's discretion after joint neurology and travel medicine consultation including a personalized risk-benefit analysis; relapse in the preceding 4-6 weeks is an absolute contraindication. YFV is allowed in some patients receiving natalizumab, given its selective targeting of alpha4-betal integrin. MRI is routinely performed for clinical follow-up on an annual basis and additionally in the event of a suspected relapse. It was not scheduled prospectively for research purposes for any of these patients; MRI dates were thus essentially random in the years before and after vaccination.

Absolute study exclusion criteria were pregnancy with delivery in the 6 months after vaccination (given that fewer and more relapses may occur during pregnancy and the postpartum period, respectively ${ }^{10}$ ) and unavailable medical records.

\section{Standard protocol approvals, registrations, and patient consent}

The Geneva Cantonal Ethics Commission approved the study (2018-01663) and granted exemption from informed consent.

\section{Statistical analysis}

There was no sample size calculation; all eligible patients were included. Relapse rates were calculated by dividing the number of relapses by the time contributed by each individual during the 3 different observation periods. Analyses of potential associations between relapse and clinical characteristics could not be conducted, given the occurrence of only one ERP relapse. Descriptive analyses were performed in Stata v14 (College Station, TX).

\section{Data availability}

Anonymized data not published in the article will be shared on reasonable request from a qualified investigator.

\section{Results}

Twenty-three patients with MS receiving YFV were included (figure e-2, links.lww.com/NXI/A249). Twenty had relapsing MS, and 3 had primary progressive MS; the mean age was 34 years ( $\mathrm{SD} \pm 10)$, and most $(17 / 23,74 \%)$ were women (table 1). Ten patients $(43 \%)$ were receiving disease-modifying therapy (DMT), and 8 of them were receiving natalizumab; at 90 days postvaccination, $15(65 \%)$ patients were receiving DMT. Twenty of 23 patients (87\%) received at least one other vaccine in the study period.

In the PEP, 9 patients experienced 12 relapses (annualized relapse rate $[A R R]$ 0.52; table 2). The median time from the last relapse to YF vaccination was 198 days (IQR 63-300). These relapses also occurred before any other vaccinations were administered. In the ERP, only one patient experienced 
Table 1 Baseline demographic and clinical characteristics of included patients

\begin{tabular}{|c|c|c|c|}
\hline Characteristic & $\begin{array}{l}\text { All patients } \\
n=23\end{array}$ & $\begin{array}{l}\text { Patients with relapse after } \\
\text { YF vaccination }{ }^{a} n=4\end{array}$ & $\begin{array}{l}\text { Patients without relapses } \\
\text { after YF vaccination } n=19\end{array}$ \\
\hline Female sex (\%) & $17(74)$ & $3(75)$ & $14(74)$ \\
\hline Mean age, y (SD) & $34( \pm 10)$ & $28( \pm 4)$ & $36( \pm 10)$ \\
\hline Mean time since MS diagnosis, y (SD) & $4.2( \pm 5.7)$ & $1.2( \pm 1.7)$ & $5.0( \pm 6.2)$ \\
\hline \multicolumn{4}{|l|}{ Type of MS } \\
\hline Relapsing-remitting (\%) & $20(87)$ & $4(100)$ & $16(84)$ \\
\hline Primary progressive (\%) & $3(13)$ & $0(0)$ & $3(16)$ \\
\hline Mean EDSS (SD) at time of vaccination & $1.83( \pm 1.19)$ & $1.0( \pm 0.82)$ & $2.0( \pm 1.20)$ \\
\hline Patients receiving DMT at the time of vaccination (\%) & $10(43)$ & $1(25)$ & 9 (47) \\
\hline Natalizumab (\%) & $8(35)$ & $0(0)$ & $8(42)$ \\
\hline Glatiramer acetate (\%) & $1(4)$ & $0(0)$ & $1(5)$ \\
\hline Interferon-beta $1(\%)$ & $1(4)$ & $1(25)$ & $0(0)$ \\
\hline Median time from YF vaccination to DMT, d (IQR) ${ }^{b}$ & $47(43-70)$ & $55(32-85)$ & $47(43-47)$ \\
\hline Patients receiving DMT at $90 \mathrm{~d}$ after YF vaccination (\%) & $15(65)$ & $4(100)$ & $11(58)$ \\
\hline Natalizumab (\%) & $6(40)$ & $0(0)$ & $6(55)$ \\
\hline Fingolimod (\%) & $3(20)$ & $1(25)$ & $2(18)$ \\
\hline Dimethyl fumarate (\%) & $3(20)$ & $1(25)$ & $2(18)$ \\
\hline Rituximab (\%) & $2(13)$ & $1(25)$ & $1(9)$ \\
\hline Interferon-beta 1 (\%) & $1(7)$ & $1(25)$ & $0(0)$ \\
\hline Other vaccinations received within $7 \mathrm{~d}$ of $\mathrm{YFV}$ administration $(\%)^{\mathrm{c}}$ & $13(57)$ & $1(25)$ & $12(63)$ \\
\hline Receipt of other vaccinations in the study period (\%) ${ }^{d}$ & $20(87)$ & $3(75)$ & $17(89)$ \\
\hline Experienced a relapse in the pre-exposure risk period (\%) & 9 (39) & $1(25)$ & $8(42)$ \\
\hline
\end{tabular}

Abbreviations: DMT = disease-modifying therapy; EDSS = Expanded Disability Status Scale; MMR = measles $/$ mumps $/$ rubella; YF = yellow fever; YFV = yellow fever vaccine.

${ }^{a}$ These patients had a relapse in either the exposure-risk period $(n=1)$ or the postrisk period $(n=3)$.

${ }^{b}$ DMT was introduced in 8 patients in the year after YF vaccination (5 received none and 10 were already receiving it at vaccination).

c These included hepatitis A, hepatitis B, conjugate pneumococcal, conjugate meningococcal, diphtheria/tetanus, rabies, influenza (inactivated), typhoid (inactivated), and MMR vaccines. The MMR vaccine was the only other live-attenuated vaccine administered; 2 patients received it at the time of $\mathrm{YF}$ vaccination, and neither had a relapse in the year thereafter.

${ }^{d}$ These included hepatitis A, hepatitis B, hepatitis A and B (combined), conjugate pneumococcal, conjugate meningococcal, diphtheria/tetanus, rabies, influenza (inactivated), typhoid (inactivated), tick-borne encephalitis, and MMR vaccines. The MMR vaccine was the only other live-attenuated vaccine administered; 4 patients received it in the study period, and one (25\%) had a relapse in the year following YF vaccination.

one relapse (ARR 0.17) 32 days after vaccination. The ERP/ $\mathrm{PEP}$ rate ratio was 0.333 (95\% CI 0.008-2.253). In the PRP, 3 other patients experienced one relapse each (ARR 0.13) 126, 247 , and 281 days after vaccination, respectively. Three of the 4 patients experiencing a relapse in the year after YF immunization had experienced a relapse in the PEP.

Steroids were administered for 12 of 16 relapses (75\%), with 10 of $12(83 \%), 1$ of $1(100 \%)$ and 1 of $3(33 \%)$ requiring high-dose methylprednisolone in the PEP, ERP, and PRP, respectively. Mean Expanded Disability Status Scale scores for patients with relapses during the PEP, ERP, and PRP were 2.2 (SD \pm 1.3 ), 2.0 (SD 0), and 1.0 (SD 0), respectively.
In the PEP, ERP, and PRP, 18, 2, and 9 patients had new brain and/or spinal lesions on T2 or T1Gd + MRI, respectively. These were not associated with a relapse in 9, 1, and 6 patients, respectively (table 3 ).

\section{Discussion}

In the largest cohort to date of patients with MS receiving YFV, we did not observe increased relapse rates postvaccination. Instead, we found a sharp decrease in the ARR from 0.52 before to 0.17 and 0.13 after YFV. This contrasts with the report of an increased density of exacerbations after vaccination. ${ }^{6}$ 
Table 2 Multiple sclerosis relapses in the pre-exposure risk period, the exposure-risk period, and the postrisk period (the 12 months before, the 3 months after, and the 4 to 12 months after YF vaccination, respectively)

\begin{tabular}{llll}
\hline & PEP & ERP & PRP \\
\hline No. of relapses & 12 & $1^{c}$ & 3 \\
\hline No. of patients with relapses (\%) $^{\mathbf{a}}$ & $9(39)$ & $1(4)$ & $3(13)$ \\
\hline Incidence rate (relapse/patient-year) $^{\mathbf{b}}$ & 0.52 & 0.17 & 0.13 \\
\hline
\end{tabular}

Abbreviations: $\mathrm{ERP}=$ exposure-risk period; $\mathrm{PEP}=$ pre-exposure period; $\mathrm{PRP}=$ postrisk period; $\mathrm{YFV}=$ yellow fever vaccine.

${ }^{a} p$ value is 0.010 for comparison between pre-exposure risk period and exposure-risk period (Fisher exact).

${ }^{b}$ Rate ratio is $0.333(95 \% \mathrm{Cl} 0.008-2.253)$ for the exposure-risk period vs the pre-exposure period.

c Relapse occurred $32 \mathrm{~d}$ after YFV.

The difference may be explained by several factors. First, $43 \%$ of our patients were receiving DMT at the time of YFV. This proportion increased to $65 \% 3$ months later: at our center, an effort is made to vaccinate patients with MS before a new DMT is begun. Second, today's MS therapies are more effective than 10 years ago. Together these factors likely contribute to lower the ARR in the ERP-demonstrating, nonetheless, that YFV may be well-tolerated even in patients with MS experiencing a relapse in the previous year.

Farez et al. reported that 5 of 7 patients experienced 14 relapses (including 5 relapses within 6 weeks after YFV), without specifying the number of relapsing patients. A clustering effect, with a few patients experiencing multiple relapses, cannot be ruled out. Neither individual relapse events nor DMT changes in the pre-exposure or postexposure periods were reported: a patient undergoing YFV probably has not had a recent relapse, and the longer a relapse has not occurred, the more imminent the next one becomes. ${ }^{11}$

Although natalizumab is not recommended for coadministration with live-attenuated vaccines, no natalizumab recipient experienced a YFV-related adverse event or relapsed after YFV. Conversely, lack of DMT at or shortly after YFV was not a risk for relapse: none were observed in the month after vaccination, when most patients were not treated or not yet highly immunosuppressed and during which autoimmune phenomena may occur after viral infections. ${ }^{5}$

Our study has limitations: given its retrospective nature, we cannot exclude the possibility that asymptomatic MRI lesions were missed, although we included only patients with MS with regular follow-up. The study's sample size is limited, yet it is over 3 times that of the only report on the subject. ${ }^{6} \mathrm{We}$ included 3 patients with primary progressive MS; by definition, persons with this form of disease have not experienced classic relapse before clinical progression and do not typically experience relapse thereafter. Nonetheless, a potential for clinically discernible relapse in this group is recognized ${ }^{12}$; their clinical courses may thus be of value to a currently modest evidence base.

This study provides Class IV evidence that YFV may be welltolerated by patients with MS. Prospective, controlled studies are warranted to confirm these findings.

\section{Acknowledgment}

The authors thank Fabienne Marechal-Rouiller and Nathalie Soumet Trinquart for preparation of the case-report form.

Table 3 New brain and/or spinal cord lesions found on T2 or T1 Gad + MRI during the 3 study periods

\begin{tabular}{|c|c|c|c|}
\hline & PEP & ERP & PRP \\
\hline Patients undergoing MRI, $n$ & 22 & 8 & 20 \\
\hline Median time until YFV, d (IQR) & $73(39-150)$ & NA & NA \\
\hline Median time since YFV, d (IQR) & NA & $40(23-64)$ & $220(186-274)$ \\
\hline Patients with new MRI lesions ${ }^{a}(\%)$ & $18(82)$ & $2(25)$ & $9(45)$ \\
\hline Patients with new T1Gad + lesions (\%) & $10(56)$ & $1(50)$ & $4(44)$ \\
\hline Patients with new T2 lesions ${ }^{b}(\%)$ & $14(78)$ & $2(100)$ & $6(67)$ \\
\hline Patients with asymptomatic lesions (\%) & $9(50)$ & $1(50)$ & $6(67)$ \\
\hline
\end{tabular}

Abbreviations: $E R P=$ exposure-risk period; $N A=$ not applicable; $P E P=$ pre-exposure period; $P R P=$ postrisk period; $Y F V=$ yellow fever vaccination .

a Lesion(s) not present on any MRI before the MRI during the corresponding study period and found on T2 and/or T1Gad + imaging.

${ }^{\mathrm{b}}$ Without gadolinium enhancement on T1-weighted sequences. 


\section{Study funding}

No targeted funding reported.

\section{Disclosure}

P.H. Lalive has received honoraria for speaking from Biogen Idec, CSL Behring, Merck Serono, Novartis, Sanofi-Aventis, Teva, Roche; consulting fees from Biogen Idec, GeNeuro, Genzyme, Merck Serono, Novartis, Sanofi-Aventis, Teva; and research grants from Biogen Idec, Merck Serono, and Novartis. All other authors report no disclosures. Go to Neurology.org/NN for full disclosures.

\section{Publication history}

Received by Neurology: Neuroimmunology \& Neuroinflammation October 22, 2019. Accepted in final form March 20, 2020.

\section{Appendix Authors}

\begin{tabular}{|c|c|c|}
\hline Name & Location & Contribution \\
\hline $\begin{array}{l}\text { Angela } \\
\text { Huttner, } \\
\text { MD }\end{array}$ & $\begin{array}{l}\text { Geneva University } \\
\text { Hospitals, Switzerland }\end{array}$ & $\begin{array}{l}\text { Study design, data analysis, } \\
\text { and drafting of the } \\
\text { manuscript }\end{array}$ \\
\hline $\begin{array}{l}\text { Gilles } \\
\text { Eperon, } \\
\text { MD }\end{array}$ & $\begin{array}{l}\text { Geneva University } \\
\text { Hospitals, Switzerland }\end{array}$ & $\begin{array}{l}\text { Study conceptualization } \\
\text { and design, data collection } \\
\text { and interpretation, and } \\
\text { manuscript revision }\end{array}$ \\
\hline $\begin{array}{l}\text { Agustina } \\
\text { M. } \\
\text { Lascano, } \\
\text { MD, PhD }\end{array}$ & $\begin{array}{l}\text { Geneva University } \\
\text { Hospitals, Switzerland }\end{array}$ & $\begin{array}{l}\text { Data collection and } \\
\text { interpretation and } \\
\text { manuscript revision }\end{array}$ \\
\hline $\begin{array}{l}\text { Serge } \\
\text { Roth, MD }\end{array}$ & $\begin{array}{l}\text { Geneva University } \\
\text { Hospitals, Switzerland }\end{array}$ & $\begin{array}{l}\text { Data collection and } \\
\text { interpretation and } \\
\text { manuscript revision }\end{array}$ \\
\hline
\end{tabular}

Appendix (continued)

\begin{tabular}{lll}
\hline Name & Location & Contribution \\
\hline $\begin{array}{l}\text { Jean Marc } \\
\text { Schwob, } \\
\text { MD }\end{array}$ & $\begin{array}{l}\text { Geneva University } \\
\text { Hospitals, Switzerland }\end{array}$ & $\begin{array}{l}\text { Data collection and } \\
\text { interpretation and } \\
\text { manuscript revision }\end{array}$ \\
\hline $\begin{array}{l}\text { Claire- } \\
\text { Anne } \\
\text { Siegrist, } \\
\text { MD }\end{array}$ & $\begin{array}{l}\text { University of Geneva } \\
\text { and Geneva University }\end{array}$ & $\begin{array}{l}\text { Study conceptualization } \\
\text { and design, data } \\
\text { interpretation, and } \\
\text { manuscript revision }\end{array}$ \\
\hline $\begin{array}{l}\text { Patrice H. } \\
\text { Lalive, MD }\end{array}$ & $\begin{array}{l}\text { University of Geneva } \\
\text { and Geneva University }\end{array}$ & $\begin{array}{l}\text { Study conceptualization } \\
\text { and design, data } \\
\text { interpretation, and } \\
\text { mospitals, Switzerland }\end{array}$ \\
& &
\end{tabular}

\section{References}

1. Monath TP, Vasconcelos PF. Yellow fever. J Clin Virol 2015;64:160-173.

2. Domingo C, Niedrig M. Safety of $17 \mathrm{D}$ derived yellow fever vaccines. Expert Opin Drug Saf 2009;8:211-221.

3. Seligman SJ. Risk groups for yellow fever vaccine-associated viscerotropic disease (YEL-AVD). Vaccine 2014;32:5769-5775.

4. Ercolini AM, Miller SD. The role of infections in autoimmune disease. Clin Exp Immunol 2009; 155:1-15.

5. Buljevac D, Flach HZ, Hop WC, et al. Prospective study on the relationship between infections and multiple sclerosis exacerbations. Brain 2002;125:952-960.

6. Farez MF, Correale J. Yellow fever vaccination and increased relapse rate in travelers with multiple sclerosis. Arch Neurol 2011;68:1267-1271.

7. Petersen I, Douglas I, Whitaker H. Self controlled case series methods: an alternative to standard epidemiological study designs. BMJ 2016;354:i4515.

8. Erbayat Altay E, Fisher E, Jones SE, Hara-Cleaver C, Lee JC, Rudick RA. Reliability of classifying multiple sclerosis disease activity using magnetic resonance imaging in a multiple sclerosis clinic. JAMA Neurol 2013;70:338-344.

9. Thompson AJ, Banwell BL, Barkhof F, et al. Diagnosis of multiple sclerosis: 2017 revisions of the McDonald criteria. Lancet Neurol 2018;17:162-173.

10. Harbo HF, Gold R, Tintore M. Sex and gender issues in multiple sclerosis. Ther Adv Neurol Disord 2013;6:237-248.

11. Pool V, Gordon DM, Decker M. Methodological issues with the risk of relapse study in patients with multiple sclerosis after yellow fever vaccination. Arch Neurol 2012;69:144.

12. Lublin FD, Reingold SC, Cohen JA, et al. Defining the clinical course of multiple sclerosis: the 2013 revisions. Neurology 2014;83:278-286. 


\section{Neurology \\ Neuroimmunology \& Neuroinflammation}

Risk of MS relapse after yellow fever vaccination: A self-controlled case series

Angela Huttner, Gilles Eperon, Agustina M. Lascano, et al.

Neurol Neuroimmunol Neuroinflamm 2020;7;

DOI 10.1212/NXI.0000000000000726

This information is current as of May 1, 2020

\section{Updated Information \& Services}

References

Subspecialty Collections

Permissions \& Licensing

Reprints including high resolution figures, can be found at:

http://nn.neurology.org/content/7/4/e726.full.html

This article cites 12 articles, 1 of which you can access for free at: http://nn.neurology.org/content/7/4/e726.full.html\#\#ref-list-1

This article, along with others on similar topics, appears in the following collection(s):

Multiple sclerosis

http://nn.neurology.org//cgi/collection/multiple_sclerosis

Information about reproducing this article in parts (figures,tables) or in its entirety can be found online at:

http://nn.neurology.org/misc/about.xhtml\#permissions

Information about ordering reprints can be found online: http://nn.neurology.org/misc/addir.xhtml\#reprintsus

Neurol Neuroimmunol Neuroinflamm is an official journal of the American Academy of Neurology.

Published since April 2014, it is an open-access, online-only, continuous publication journal. Copyright

Copyright $\odot 2020$ The Author(s). Published by Wolters Kluwer Health, Inc. on behalf of the American

Academy of Neurology.. All rights reserved. Online ISSN: 2332-7812.

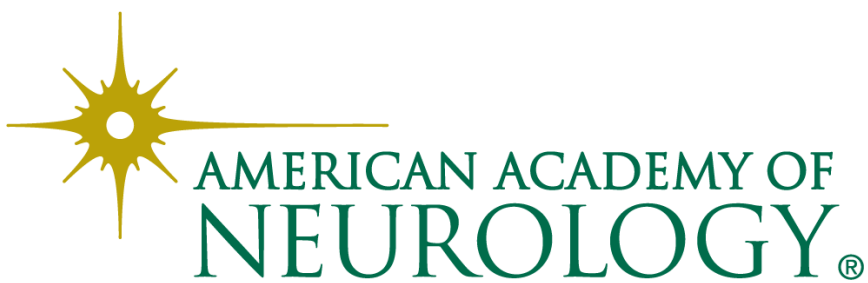

